ВАКУЛИК О.О.

\author{
ТАКТИКО-КРИМІНАЛІСТИЧНЕ ЗАБЕЗПЕЧЕННЯ \\ ПРОВЕДЕННЯ СЛІДЧОГО ЕКСПЕРИМЕНТУ \\ ПІД ЧАС РОЗСЛІДУВАННЯ ДОРОЖНЬО-ТРАНСПОРТНИХ ПРИГОД
}

\title{
TACTICAL-CRIMINAL SUPPORT OF THE INVESTIGATIVE EXPERIMENT IN THE INVESTIGATION ROAD ACCIDENTS
}

Метою статті є дослідження тактико-криміналістичного забезпечення проведення слідчого експерименту під час розслідування дорожньо-транспортних пригод. Завданнями дослідження у статті є розгляд поняття тактико-криміналістичного забезпечення; аналіз тактико-криміналістичного забезпечення проведення слідчого експерименту під час розслідування дорожньо-транспортних пригод. У статті розглянуто окремі аспекти тактико-криміналістичного забезпечення проведення слідчого експерименту під час розслідування дорожньо-транспортних пригод. Основними завданнями дослідження є розгляд поняття тактико-криміналістичного забезпечення та з'ясування того, яким воно $є$ у кримінальних провадженнях під час розслідування дорожньо-транспортних пригод. У результаті дослідження запропоновано виділити серед тактико-криміналістичного забезпечення проведення слідчого експерименту під час розслідування дорожньо-транспортних пригод такі елементи, як проведення в умовах, максимально наближених до тих, у яких відбувалась подія; використання тих же приладів, механізмів, пристроїв та матеріалів, що використовувалися під час події; забезпечення заходів безпеки під час його проведення; обов'язкова участь спеціаліста; забезпечення участі потерпілого, свідка, підозрюваного. Звернено увагу на організаційні й тактичні труднощі, які виникають під час проведення слідчого експерименту в ході розслідування дорожньо-транспортних пригод, особливо щодо створення умов, максимально наближених до обставин події, використання тих же приладів, механізмів, що використовувалися під час події. Зроблено висновок про необхідність обов'язкового залучення до проведення слідчого експерименту у справах про дорожньо-транспортні пригоди спеціаліста, зокрема експерта-автотехніка. Акцентовано увагу на необхідності роз'яснення прав учасникам слідчого експерименту перед його проведенням, зокрема права не свідчити проти себе. Зроблено висновок, що слідчий експеримент під час розслідування дорожньо-транспортних пригод $є$ важливим способом отримання доказів у кримінальному провадженні. Його проведення має бути чітко організованим з відповідним тактико-криміналістичним забезпеченням (проведення в умовах, максимально наближених до тих, у яких відбувалась подія; використання тих же приладів, механізмів, пристроїв та матеріалів, що використовувалися під час події; забезпечення заходів безпеки під час його проведення; обов'язкова участь спеціаліста; забезпечення участі потерпілого, свідка, підозрюваного).

(C) ВАКУЛИК О.О. - кандидат юридичних наук, доцент, доцент кафедри криміналістики та судової медицини (Національна академія внутрішніх справ) 
Ключові слова: тактико-криміналістичне забезпечення, слідчий експеримент, дорожньо-транспортна пригода, слідча (розшукова) дія.

The purpose of the article is to study the tactical and forensic support of the investigative experiment in the investigation of road accidents. The objectives of the study in this article are: consideration of the concept of tactical and forensic support; analysis of tactical and forensic support of the investigative experiment in the investigation of road accidents. The article considers some aspects of tactical and forensic support of the investigative experiment in the investigation of road accidents. The main objectives of the study are to consider the concept of "tactical and forensic support" and to find out what it is in criminal proceedings in the investigation of road accidents. As a result of the research, it is proposed to distinguish the following elements among the tactical and forensic support of the investigative experiment in the investigation of road accidents: conducting in conditions as close as possible to those in which the event took place; use of the same devices, mechanisms, devices and materials used during the event; ensuring security measures during its implementation; mandatory participation of a specialist; ensuring the participation of the victim, witness, suspect. Attention is paid to the organizational and tactical difficulties that arise during the investigative experiment in the investigation of road accidents, especially with regard to creating conditions as close as possible to the circumstances of the event, the use of the same devices and mechanisms used during the event. It was concluded that it is necessary to involve a specialist, in particular a car expert, in the investigation of road accidents. Emphasis is placed on the need to explain the rights of participants in the investigative experiment before it is conducted, in particular the right not to testify against oneself. It is concluded that the investigative experiment in the investigation of road accidents is an important way to obtain evidence in criminal proceedings. Its conduct should be clearly organized with appropriate tactical and forensic support: conduct in conditions as close as possible to those in which the event took place; use of the same devices, mechanisms, devices and materials used during the event; ensuring security measures during its implementation; mandatory participation of a specialist; ensuring the participation of the victim, witness, suspect.

Key words: tactical and forensic support, investigative experiment, traffic accident, investigative (search) action.

Вступ. Досягнення мети кримінального провадження безпосередньо залежить від якості провадження слідчих (розшукових) дій. Під час розслідування дорожньо-транспортних пригод (далі - ДТП) вагоме значення у встановленні істини у справі належить слідчому експерименту. Результати слідчого експерименту є підгрунтям проведення автотехнічної (інженерно-транспортної) експертизи, якою встановлюється механізм ДТП через зв'язок із законами механіки руху, взаємодії вузлів, агрегатів транспортного засобу, особливостей реакції водія на зміну дорожньої обстановки. Попри поширеність, у правозастосовній діяльності з реалізацією зазначеної слідчої (розшукової) дії виникають певні труднощі, що пов'язані як із недосконалістю правового регулювання слідчого експерименту, так і зі складнощами організаційного характеру, що знижують ефективність цієї слідчої (розшукової) дії або взагалі зводять нанівець усі результати через визнання протоколу слідчого експерименту недопустимим доказом. Все це свідчить про актуальність вибраної теми дослідження.

Окремі організаційні й тактичні аспекти слідчого експерименту у своїх працях досліджували такі відомі вчені, як В.П. Бахін, Р.С. Бєлкін, П.Д. Біленчук, І.О. Возгрін, О.М. Васильєв, Н.І. Гуковська, В.Г. Лукашевич, С.Д. Лук'янчиков, В.О. Коновалова, В.С. Кузьмічов, В.О. Образцов, М.В. Салтевський, М.Ф. Сокиран, В.М. Тертишник, К.О. Чаплинський, В.Ю. Шепітько, М.П. Яблоков. Водночас нині на практиці виникає потреба в науково обгрунтованих криміналістичних рекомендаціях щодо тактичних особливостей проведення слідчого експерименту, зокрема під час розслідування ДТП.

Постановка завдання. Метою статті є дослідження тактико-криміналістичного забезпечення проведення слідчого експерименту під час розслідування ДТП. Завданнями дослідження у статті є розгляд поняття тактико-криміналістичного забезпечення; аналіз тактико-криміналістичного забезпечення проведення слідчого експерименту під час розслідування ДТП. 
Результати дослідження. Для розслідування ДТП слідчий експеримент має суттєве доказове й тактичне значення, адже більшість обставин, які впливають на оцінку дій водіїв та інших учасників, можуть бути встановлені, уточнені та перевірені лише в рамках цієї слідчої (розшукової) дії. Відповідно до ст. 240 КПК України, задля перевірки та уточнення відомостей, які мають значення для встановлення обставин кримінального правопорушення, слідчий, прокурор мають право провести слідчий експеримент шляхом відтворення дій, обставин певної події, проведення необхідних дослідів чи випробувань [1].

Слідчий експеримент належить до слідчої (розшукової) дії, за якої здійснюється виявлення та фіксація не лише невербальної інформації про обставини вчиненої події, але й вербальної, а саме пояснень його учасників. В теорії криміналістики такі слідчі (розшукові) дії прийнято називати змішаними. І.В. Гора, В.А. Колесник зазначають, що змішані слідчі дії спрямовані на отримання доказової інформації від змішаних джерел («люди-речі»), тобто в їх результаті одержується як словесна інформація від особи, що повідомляє ії усно або в письмовій формі, так і така, що міститься в об'єктах матеріального світу та в їх матеріальних відображеннях. До таких слідчих дій вони відносять, зокрема, слідчий експеримент [2, с. 251].

С.О. Жувака зазначає, що слідчий експеримент є специфічною слідчою дією, під час якої відбувається взаємодія як із речовими джерелами інформації, так і з ідеальними слідами (слідами пам'яті людини) [3, с. 103].

Такий змішаний характер цієї слідчої (розшукової) дії обумовлює особливі тактичні прийоми іiі проведення. Ефективність слідчого експерименту зумовлена рівнем криміналістичного забезпечення під час його проведення, впровадженням досягнень науково-технічного прогресу, тактичних рекомендацій для досягнення мети.

У криміналістиці систему рекомендацій, прийомів, комбінацій, спрямованих на підвищення ефективності слідчих (розшукових) дій та розв'язання задач кримінального судочинства, 3 урахуванням їі специфіки прийнято називати тактико-криміналістичним забезпеченням. На думку К.О. Чаплинського, зміст тактичного забезпечення полягає в озброєнні спеціально уповноважених осіб органів дізнання й досудового слідства новітніми та апробованими засобами криміналістичної тактики для ефективного проведення слідчих дій задля розв'язання слідчих ситуацій, що формуються на кожному етапі розслідування, та вирішення завдань кримінального судочинства [4, с. 10-11]. Цей термін використовує у своїй монографії також Ю.М. Чорноус [5, с. 64].

Аналіз поглядів учених-криміналістів свідчить про те, що деякі з них розглядають криміналістичне забезпечення як діяльність зі створення умов для ефективного використання криміналістичних методів, засобів і рекомендацій задля розкриття й розслідування злочинів та встановлення істини у кримінальному провадженні [6, с. 18].

3 урахуванням викладених позицій нами пропонується розглядати тактико-криміналістичне забезпечення проведення слідчого експерименту під час розслідування ДТП як діяльність зі створення умов для ефективного використання криміналістичних методів, засобів і рекомендацій в ході проведення слідчого експерименту для встановлення обставин, що підлягають доказуванню під час розслідування ДТП.

Під час розслідування ДТП слідчий експеримент є одним із найважливіших засобів установлення обставин кримінального провадження, а від порядку його організації, правильності проведення як у процесуальному, так і в тактичному аспектах залежить подальший успіх розслідування. Нами були виокремлені найважливіші, на нашу думку, елементи тактико-криміналістичного забезпечення проведення слідчого експерименту під час розслідування ДТП, такі як проведення в умовах, максимально наближених до тих, у яких відбувалась подія; використання тих же приладів, механізмів, пристроїв та матеріалів, що використовувались під час кримінально протиправної події; забезпечення заходів безпеки під час проведення; участь спеціаліста у його проведенні; участь потерпілого, свідка, підозрюваного.

Проведення в умовах, максимально наближених до тих, у яких відбувалась подія.

Ця умова полягає в тому, що слідчий експеримент проводиться у максимально наближеній обстановці, у якій відбувалася сама подія, у тому числі за того ж освітлення, погодних умов, стану дорожнього покриття. Ця умова $є$ однією з обов'язкових, невиконання якої призводить до неможливості досягнення мети проведення цієї слідчої (розшукової) дії. Як зазначає Ф.М. Сокиран, недотримання цієї умови розцінюється як порушення вимог кримінального процесуального закону, що спричиняє втрату доказового значення одержаних даних [7, с. 271]. Водночас виконати іiі дуже складно як організаційно, так і практично. Так, якщо ДТП було в умовах туману чи ожеледиці, то такі погодні умови не можна штучно створити, змоделювати чи іншим чином ство- 
рити подібну обстановку, окрім як чекати такі ж метеорологічні умови для проведення експерименту. Все це призводить до затягування розслідування, неможливості прийняття процесуальних рішень по кримінальних провадженнях. Водночас ця умова зумовлює вимогу ретельної підготовки до проведення слідчого експерименту, адже повторне його проведення може бути можливим через тривалий час.

Використання тих же приладів, механізмів, пристроїв та матеріалів, щэо використовувалися під час кримінально протиправної події.

Розкриваючи цю тактичну умову слідчого експерименту, Ю.А. Чаплинська наголошує на доцільності використання під час його проведення тих самих приладів, пристроїв чи механізмів, однак допускає за неможливості використання зазначених об'єктів у експерименті застосовувати предмети-аналоги або натурні макети $[8$, с. 252]. Зауважимо, що використати під час проведення слідчого експерименту в ході розслідування ДТП інші, аналогічні транспортні засоби, а не ті, що були безпосередньо під час події, здебільшого неможливо, адже, незважаючи на однакову модель транспортного засобу, технічний стан кожного з них визначається індивідуальними особливостями. У зв'язку з цим проведення слідчого експерименту ускладняється, адже часто транспортний засіб учасника ДТП знаходиться у несправному після події стані. У практичній діяльності видимість та оглядовість 3 робочого місця водія, як правило, проводяться одразу під час огляду місця ДТП (якщо дозволяє стан транспортного засобу та обставини події), оскільки за не встановлення зазначених обставин під час огляду місця події дуже важко це буде реконструювати в подальшому на цьому ж транспортному засобі у тих же погодних умовах.

Забезпечення заходів безпеки під час проведення слідчого експерименту.

У науковій літературі є позиція, за якою такий елемент слід віднести до вимоги, що висувається до слідчої дії [9, с. 348]. Відповідно до ч. 4 ст. 240 КПК України, проведення слідчого експерименту допускається за умови, що при цьому не створюється небезпека для життя й здоров'я осіб, які беруть у ньому участь, чи оточуючих, не принижуються їхня честь і гідність, не завдається шкоди [1]. Під час проведення слідчого експерименту у кримінальних провадженнях у сфері забезпечення безпеки дорожнього руху ця умова набуває особливої значимості і вимагає особливої організації, оскільки від цього залежить безпека не лише учасників цієї слідчої (розшукової) дії, але й інших учасників дорожнього руху. Так, під час підготовки до його проведення необхідно забезпечити участь додаткових учасників, а саме інспекторів патрульної поліції, сектору реагування патрульної поліції чи інших працівників, які мають забезпечити безпеку руху під час його проведення. Оскільки тривалість слідчого експерименту може складати не одну годину, необхідно забезпечити рух транспортних засобів (об’їзд чи регулювання руху на цей час). Окрім цього, така необхідність зумовлена підвищеним рівнем ризику проведення цієї слідчої (розшукової) дії, адже під час її проведення експериментально здійснюються екстрене гальмування транспортного засобу, різка зміна руху, маневрування (залежно від обставин ДТП), тому важливо, щоби під час проведення таких дій не постраждали як самі учасники слідчої (розшукової) дії, так і сторонні особи.

Участь спеціаліста у проведенні слідчого експерименту.

У ч. 2 ст. 240 КПК України участь спеціаліста у проведенні слідчого експерименту не $\epsilon$ імперативною нормою, а здійснюється на розсуд слідчого. На нашу думку, участь спеціаліста під час проведення слідчого експерименту у кримінальних провадженнях щодо ДТП має бути обов’язковою. Аргументами на користь цієї позиції є такі. Спеціаліст під час проведення слідчої (розшукової) дії здійснюватиме технічну допомогу у моделюванні обстановки ДТП, під час проведення експериментів та дослідницьких дій (замірів шляху гальмування, встановлення швидкості, встановлення видимості тощо) коригуватиме досліди чи випробування, використовуючи свої спеціальні знання, ставлячи уточнюючі запитання учасникам слідчого експерименту, буде виявляти розбіжності, розтлумачувати певні результати.

Зауважимо, що позиція щодо обов'язкової участі спеціаліста під час проведення слідчого експерименту не $є$ новою у теорії криміналістики. Зокрема, В.Я. Радецька, С.О. Гусаченко вважають, що іноді участь конкретного спеціаліста з криміналістичних позицій слід визнати обов'язковою вимогою ефективності слідчої дії та об'єктивності отриманих результатів (наприклад, слідчий експеримент за участю спеціаліста в галузі авто-технічної експертизи під час проведення відтворення механізму дорожньо-транспортної події) [10, с. 246]. Про доцільність залучення спеціалістів під час проведення слідчого експерименту в ході розслідування ДТП говорить I.I. Колеснік, який наголошує на тому, що, «зважаючи на те, що слідчий експеримент є необхідним для проведення низки експертиз, підкреслюємо, що визначення його конкретної мети та умов 
проведення повинно бути узгоджено з відповідними експертами, а в багатьох випадках доцільно їх залучати до його проведення як спеціалістів» [11, с. 215].

Окрім вищезазначених авторів, аргументує доцільність залучення до проведення слідчого експерименту під час ДТП як спеціаліста автотехніка у своєму дослідженні Є.О. Даніч $[12$, с. 179], наголошуючи на тому, що «за умов, коли за результатами слідчого експерименту необхідно встановити вплив технічного стану окремих агрегатів і механізмів на динамічні якості та керованість автомобіля, різні експлуатаційні якості конкретного транспортного засобу у визначених дорожніх умовах, необхідним є залучення спеціаліста-автотехніка».

Значення участі спеціалістів у проведенні слідчого експерименту під час розслідування ДТП важко переоцінити. Як спеціалістів доцільно залучати, окрім експерта-автотехніка, судово-медичного лікаря (особливо у разі спричинення смерті потерпілому). При цьому судово-медичний експерт може зробити попередні висновки щодо спричинених тілесних ушкоджень, механізму їх утворення та локалізації, надати попередній висновок про те, чи характерні вони для ДТП. Експерт-автотехнік у процесі проведення слідчого експерименту може надати слідчому консультаційну та технічну допомогу, що будуть враховані під час проведення експертиз зі встановлення механізму ДТП.

Участь потерпілого, свідка, підозрюваного у слідчому експерименті.

Слідчий експеримент, як визначено у ч. 1 ст. 241 КПК України, проводиться задля перевірки та уточнення відомостей, які мають значення для встановлення обставин кримінального правопорушення. Іншими словами, він належить до перевірочних слідчих (розшукових) дій. Його проведення можливе лише після збору первинної інформації про обставини ДТП, що відбувається шляхом проведення огляду місця події, допиту потерпілих, свідків. Попередній допит особи, чиї показання будуть підлягати перевірці, як одну з умов проведення слідчого експерименту виділяє С.О. Жувака [3, с. 103].

Зауважимо, що для більш максимального відтворення обстановки події та наближення іiі до обстановки слідчого експерименту, що є запорукою ефективного його проведення, необхідно залучити самих учасників такої події, а саме потерпілих, свідків, підозрюваних, їх представників та захисників. Водночас, як слушно зауважує Н.В. Рогатинська, слід враховувати, що Конституція України (ст. 63) і КПК України надають підозрюваному право не свідчити проти самого себе і своїх близьких родичів. Таким чином, згода на участь у слідчому експерименті, а також надання показань під час нього є правом підозрюваного, а не обов'язком [13, с. 150].

Забезпечення права не свідчити проти себе стосується учасників слідчого експерименту під час розслідування не лише ДТП, але й інших видів кримінальних правопорушень, однак зауважимо, що залежність результатів слідчого експерименту від попереднього допиту осіб учасників ДТП є надто високою. Через те, що процесуальний статус водіїв - учасників ДТП не завжди можна визначити, всі вони у практичній діяльності попередньо допитуються як свідки, хоча в подальшому за результатами слідчого експерименту та висновку автотехнічної експертизи можуть набути статусу підозрюваного. Наведемо приклад судової практики. У постанові ВС від 10 вересня 2019 року здійснено перегляд судового рішення Апеляційного суду Житомирської області, яким було закрите кримінальне провадження по обвинуваченню ОСОБИ за ч. 2 ст. 286 КК України. За обставинами справ, 14 січня 2015 року було проведено слідчий експеримент за участю ОСОБА_1 в процесуальному статусі свідка, який у подальшому у провадженні набув статусу підозрюваного та обвинуваченого [14].

Незважаючи на те, що питання процесуального порядку проведення допиту осіб і подальшого проведення 3 ними слідчого експерименту не входить до предмета нашого дослідження, а повинно бути досліджене у площині кримінальної процесуальної діяльності, а не криміналістики, все ж таки слід наголосити на тому, що до особливих тактичних умов проведення слідчого експерименту у цій категорії проваджень належить залежність від проведення попереднього допиту осіб - учасників ДТП відповідно до вимог КПК України, що обов'язково має бути враховано під час підготовки до проведення цієї слідчої (розшукової) дії, тому, розглядаючи таку тактичну умову слідчого експерименту, як забезпечення участі свідка, потерпілого та підозрюваного під час його проведення, наголосимо на тому, що перед проведенням цієї слідчої (розшукової) дії всім учасникам мають бути роз'яснені їх права та обов'язки відповідно до їх процесуального статусу, а всім без винятку - право від самовикриття, передбачене ст. 63 Конституції України.

Науковою новизною дослідження стало виокремлення елементів тактико-криміналістичного забезпечення слідчого експерименту під час розслідування ДТП. 
Висновки. Отже, слідчий експеримент під час розслідування ДТП є важливим способом отримання доказів у кримінальному провадженні. Його проведення має бути чітко організованим 3 відповідним тактико-криміналістичним забезпеченням, таким як проведення в умовах, максимально наближених до тих, у яких відбувалась подія; використання тих же приладів, механізмів, пристроїв та матеріалів, що використовувалися під час події; забезпечення заходів безпеки під час його проведення; обов'язкова участь спеціаліста; забезпечення участі потерпілого, свідка, підозрюваного. Ці елементи тактико-криміналістичного забезпечення проведення слідчого експерименту під час розслідування ДТП сприятимуть ефективному проведенню цієї слідчої (розшукової) дії зі встановлення обставин вчиненого ДТП, перевірки та уточненню показань учасників кримінального провадження, повному та об'єктивному досудовому розслідуванню загалом.

\section{Список використаних джерел:}

1. Кримінальний процесуальний кодекс України : Закон України від 13 квітня 2012 року № 4651-VI. URL: https://zakon.rada.gov.ua/laws/show/4651-17.

2. Гора I.В., Колесник В.А. Слідчий експеримент чи перевірка показань особи? Bicник Луганського державного університету внутрішніх справ імені Е.О. Дідоренка. 2012. № 3. C. $248-256$.

3. Жувака С.О. Слідчий експеримент: проблеми застосування. Науковий вісник Міжнародного гуманітарного університету. Серія: Юриспрундениія. 2014. № 9-2. Т. 2. С. 102-104.

4. Чаплинський К.О. Тактичні основи забезпечення досудового розслідування : автореф. дис. ... докт. юрид. наук : спец. 12.00.09. Дніпропетровськ, 2011. 36 с.

5. Чорноус Ю.М. Криміналістичне забезпечення розслідування злочинів : монографія. Вінниця : ТОВ «Нілан-ЛТД», 2017. 492 с.

6. Журавель В.А., Павлюк Н.В., Резнікова О.І. Поняття та засоби криміналістичного забезпечення розслідування корупційних злочинів. Питання боротьби зі злочинністю. 2016. Вип. 32. С. 13-30.

7. Сокиран Ф.М. Особливості тактики психологічного впливу на обвинувачених при відтворенні обстановки і обставин подій. Теорія оперативно-службової діяльності правоохоронних органів Украӥни. Львів : Львівський інститут внутрішніх справ при Національній Академії внутрішніх справ, 2000. С. 265-271.

8. Чаплинська Ю.А. Проблемні питання слідчого експерименту. Право $і$ суспільство. 2014. № 1. C. 249-254.

9. Чернецький О.К. Підготовка до проведення слідчого експерименту. Ученые записки Таврического национального университета им. В.И. Вернадского. Серия «Юридические науки». 2011. T. 24 (63). № 1. С. 345-350.

10. Радецька В.Я., Гусаченко Є.О. Критерії використання спеціальних знань при проведенні слідчого експерименту. Криминалистика и судебная экспертиза. 2015. Вып. 60. С. 242-255. URL: http://nbuv.gov.ua/UJRN/krise_2015_60_29.

11. Колеснік I.I. Особливості підготовки і проведення слідчого експерименту при розслідуванні злочинів проти безпеки дорожнього руху та експлуатації транспорту. Вісник Харківського начіонального університету імені В.Н. Каразіна. Серія «Право». 2016. Вип. 22. С. 212-216.

12. Даніч Є.О. Використання спеціальних знань під час проведення слідчого експерименту : дис. ... канд. юрид. наук : спец. 12.00.09. Київ, 2018. 238 с.

13. Рогатинська Н.В. Деякі особливості проведення слідчого експерименту у кримінальному провадженні. Актуальні проблеми правознавства. 2016. Вип. 2. С. 149-153.

14. Постанова Верховного Суду колегією суддів Першої судової палати Касаційного кримінального суду від 10 вересня 2019 року № 295/13008/15-к. Провадження № 51-8420км18. URL: https://reyestr.court.gov.ua/Review/84481760. 